\title{
Design of mathematical model control of PV-grid interactive Z- Source inverter modulation
}

\author{
Varun Avasthy ${ }^{1}$ R Sridhar ${ }^{2}$, \\ ${ }^{I} P G$ Scholar, IEEE Member Department of Electrical and Electronics Engineering SRM University, Chennai \\ ${ }^{2}$ Asst. Professor (Sr.G) Department of Electrical \& Electronics Engineering SRM University, Chennai
}

\begin{abstract}
The paper introduces the modeling and control of z-source inverter, interfacing a Photovoltaic panel with a grid system. The main objective, of the work is to analyze the behavior of z-source inverter over a conventional inverter and boost converter arrangement. The approach is simulated as a MATLAB/SIMULINK model and results are used to study the characteristics of the proposed model. A sinusoidal waveform is produced at the inverter output, without any introduction of delay time between boost converter and inverter circuit.
\end{abstract}

Keywords: Z-source inverter (ZSI), Photovoltaic (PV) array, grid, shoot through, non shoot through, modulation index.

\section{Introduction}

Alternate energy sources such as solar, fuel cell, and wind have a wide voltage change range due to the nature of the sources. Photovoltaic cell's voltage varies with temperature and irradiation. Fuel cell stack voltage drops greatly with current. And wind generator voltage varies with wind speed and control.[1-3] The traditional voltage source inverter that has been the power conversion technology for these energy sources cannot cope with this wide voltage change nature and often requires additional voltage boost by additional dc/dc converter.

The Z-source inverters can solve this problem. This single stage power conversion technology provides a great alternative with lower cost, higher reliability, and higher efficiency. System configurations, features and results are shown for advanced power conditioning of alternate energy systems.[2,3]

The output of PV array varies frequently, and with this change, the input to converter also changes. This can lead to decrement in system stability. With a great amount of fluctuations occurring at dc side of converter system, frequency and voltage stability on ac side decreases. Moreover, for constant supply to the grid voltage and current level on the generation side should be above, grid voltage and current.[7-9] In order to achieve an efficient inversion process from PV array to the grid, a ZSI is usually employed. The main advantage of placing a ZSI is to obtain a single stage conversion of input voltage from one level to another. A ZSI boost up the input dc voltage to the required output, as well as perform ac/dc conversion.

\section{Modeling Of Pv Array}

A Photovoltaic cell is a semiconducting device, usually form by the wafers of silicon. It can also represented by a diode with its p-n junction exposed to sunlight. When the light photon, strike the PV cell electron in the valence band is ejected to cross the band gap, resulting in production of current in the cell. Generally several PV cells are connected in series and parallel, according to current or voltage requirements. PV cells are connected in parallel to increase the rated current and in series to increase the rated voltage. The, arrangement of PV cells in series or parallel is called a PV array[1].

A PV array is represented as a current source, in the model circuit shown as

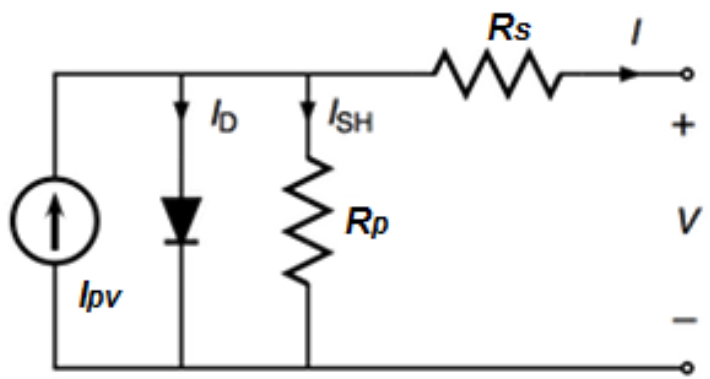

Fig.1 Model of PV array 
The circuit shown in Fig 1 is general representation of PV array with rated voltage V. For modeling a PV array with Ns cells connected in series and $\mathrm{Np}$ cells connected in parallel, I-V characteristic equation is written

$$
\mathrm{I}=\mathrm{Ipv}-\mathrm{I}_{0}\left[\exp \left(\frac{V+R s I}{V t a}\right)-1\right]-\frac{V+R s I}{R p}
$$

Rs and Rp are the series and parallel resistances in PV cells. As the PV array voltage and current depend on the irradiation of temperature received by the PV array, therefore PV current equation is given by

$$
I_{P V}=\left(I_{P V, n}+K_{I} \Delta T\right) \frac{G}{G_{n}}
$$

Here, current irradiation at rated temperature $G$ and nominal temperature $\left(T_{n}\right) G_{n}$ is introduced to find the PV array maximum power environmental condition.

The diode saturation current $I 0$ and its dependence on the temperature may be expressed by as shown:

$$
I_{o}=I_{o, n}\left(\frac{T_{n}}{T}\right)^{3} \exp \left[\frac{q E_{g}}{a k}\left(\frac{1}{T_{n}}-\frac{1}{T}\right)\right]
$$

where $E \mathrm{~g}$ is the bandgap energy of the semiconductor $(E \mathrm{~g}=1.12 \mathrm{eV}$ for the polycrystalline $\mathrm{Si}$ at $25 \circ \mathrm{C}$ [23], [42]), and $I 0, \mathrm{n}$ is the nominal saturation current:

$$
I_{o, n}=\frac{I_{s c, n}}{\exp \left(V_{o c, n} / a V_{t, n}\right)-1}
$$

\section{Z-Source Inverter Modeling}

The [2] Z-Source inverter topology was introduced in 2002, to took over the limitations of conventional inverters. The conventional inverters require dead time to avoid arm short and snubber circuits to suppress the switching spikes.

A ZSI consists of a impedance network connected in series to a three leg inverter topology. The impedance network consists of two capacitors and two inductors connected in Z-shape. With the unique impedance network of inductors and capacitors, the Z-source inverter utilizes the shoot through states by gating on both the upper and lower switches in the same phase legs, to boost the dc voltage without DC/DC converter[4,5].

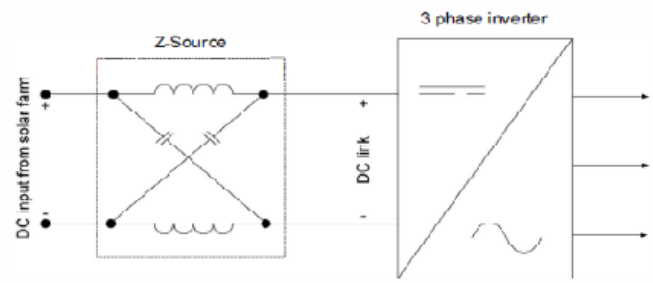

Fig.2 Z-source inverter basic circuit

\section{A. Shoot -through state of ZSI}

In the shoot through state of $\mathrm{z}$-source inverter, two switches from the same leg is turned on, since this type of operation is not allowed in the conventional inverter,[3] therefore switch $\mathrm{S}$ is turned on. For both shoot through and non shoot through modes of operation following assumptions are taken: 


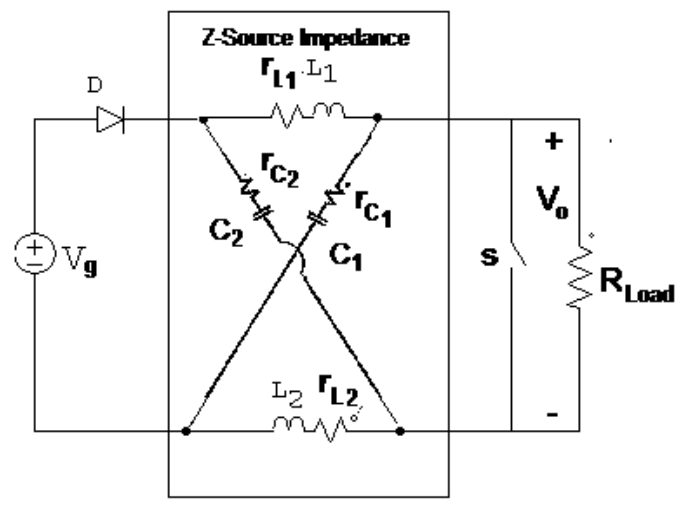

Fig 3. DC Equivalent circuit of Z-source inverter

$$
\begin{aligned}
& \mathrm{L}_{1}=\mathrm{L}_{2}=\mathrm{L} \\
& \mathrm{C}_{1}=\mathrm{C}_{2}=\mathrm{C} \\
& \mathrm{r}_{\mathrm{L} 1}=\mathrm{r}_{\mathrm{L} 2}=\mathrm{r}_{\mathrm{L}} \\
& \mathrm{r}_{\mathrm{C} 1}=\mathrm{r}_{\mathrm{C} 2}=\mathrm{r}_{\mathrm{C}}
\end{aligned}
$$

the state averaging equation for shoot through mode can be written in matrix form as follows:

$$
\left[\begin{array}{c}
L \frac{d i_{L 1}}{d t} \\
L \frac{d i_{L 2}}{d t} \\
C \frac{d v_{C 1}}{d t} \\
C \frac{d v_{C 2}}{d t}
\end{array}\right]=\left[\begin{array}{cccc}
-\left(r_{C}+r_{L}\right) & 0 & 1 & 0 \\
0 & -\left(r_{C}+r_{L}\right) & 0 & 1 \\
0 & -1 & 0 & 0 \\
-1 & 0 & 0 & 0
\end{array}\right]\left[\begin{array}{c}
i_{L 1} \\
i_{L 2} \\
v_{C 1} \\
v_{C 2}
\end{array}\right]
$$

\section{B. Non Shoot-through state of ZSI}

In non shoot through state, the inverter bridge circuit works as a resistive load. The switch $\mathrm{S}$ is open in this state, and the input diode is forward biased, allowing active or null states of the ZSI. Also, in this state the external power source charges the $\mathrm{z}$-source capacitors, though the inductors. The state averaging equations for non shoot through operation of ZSI is represented as:

$$
\begin{aligned}
& {\left[\begin{array}{c}
L \frac{d i_{L 1}}{d t} \\
L \frac{d i_{L 2}}{d t} \\
C \frac{d v_{C 1}}{d t} \\
C \frac{d v_{C 2}}{d t}
\end{array}\right]=\left[\begin{array}{cccc}
-\left(r_{C}+r_{L}\right) & 0 & 1 & 0 \\
0 & -\left(r_{C}+r_{L}\right) & 0 & 1 \\
0 & -1 & 0 & 0 \\
-1 & 0 & 0 & 0
\end{array}\right]\left[\begin{array}{l}
i_{L 1} \\
i_{L 2} \\
v_{C 1} \\
v_{C 2}
\end{array}\right]+} \\
& {\left[\begin{array}{cc}
1 & r_{c} \\
1 & r_{c} \\
0 & -1 \\
0 & -1
\end{array}\right]\left[\begin{array}{l}
v_{p v} \\
i_{a c}
\end{array}\right] }
\end{aligned}
$$

\section{Inverter Bridge Modeling}

The inverter bridge of the z-source inverter,[4,5] consists of six IGBT switches, with two switches in each leg. Each leg connected to each phase of the grid. 


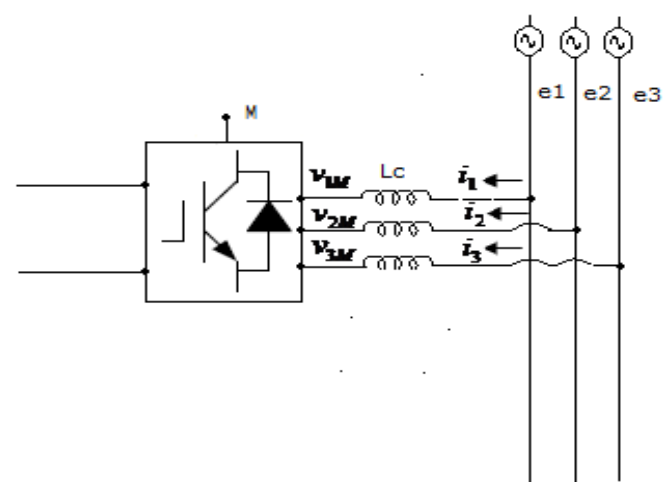

Fig.4 Equivalent circuit for Inverter-Grid interactive network

Applying, Kirchhoff's law at the AC line terminals of the bridge circuit. Assuming the absence of zero sequence component in the network, equation for voltage at the connection point can be given as:

$e_{k}=L_{C} \frac{d i_{k}}{d t}+R_{c} i_{k}+v_{k M}+v_{M N}$

$(k=1,2,3)$

Since, ac voltages are considered to be balanced

$v_{M N}=-\frac{1}{3} \sum_{m=1}^{3} v_{m M}$

For the mathematical modeling of inverter circuit following assumptions are taken in the system:

1. Switches are considered ideal, having no switching losses.

2. Three phase power source is considered to be symmetrical and positive sequence.

3. $\mathrm{AC}$ line inductors are linear without any saturation with $\mathrm{L}_{\mathrm{Cl}}=\mathrm{L}_{\mathrm{C} 2}=\mathrm{L}_{\mathrm{C} 3}=\mathrm{L}_{\mathrm{C}}$, and equivalent resistances $\mathrm{R}_{\mathrm{C} 1}=\mathrm{R}_{\mathrm{C} 2}=\mathrm{R}_{\mathrm{C} 2}=\mathrm{R}_{\mathrm{C}}$.

4. DC bus voltage is considered constant over whole non shoot through process.

By defining the switching function $\mathrm{s}_{\mathrm{k}}$ of $\mathrm{k}^{\text {th }}$ leg of inverter as:

$s_{k}=\{1$, if upper device is $\mathrm{ON}$ and lower is OFF

0 , if upper device is OFF and lower is $\mathrm{ON}$

the expression in (3) can be rewritten as

$\frac{d i_{k}}{d t}=-\frac{R_{c}}{L_{c}} i_{k}-\frac{1}{L_{C}}\left(s_{k}-\frac{1}{3} \sum_{m=1}^{3} s_{m}\right) v_{d c}+\frac{e_{k}}{L_{c}}$

$\mathrm{s}_{\mathrm{k}}(\mathrm{k}=1,2,3)$, is estimated in discrete form, for the switching frequency of the inverter greater than the modulation frequency approximately as follows:

$\mathrm{s}_{1} \approx \frac{m \cos (\omega t)+1}{2}$
$\mathrm{~s}_{2} \approx \frac{m \cos (\omega t-2 \pi / 3)+1}{2}$
$\mathrm{~s}_{3} \approx \frac{m \cos (\omega t+2 \pi / 3)+1}{2}$

IV. Operation And Control Z-Source Inverter 
With [6] respect to the capacitor voltages $\mathrm{v}_{\mathrm{C} 1}, \mathrm{v}_{\mathrm{C} 2}$ and inductor currents $\mathrm{i}_{\mathrm{L} 1}, \mathrm{i}_{\mathrm{L} 2}$ in the shoot through state, the duty ratio is represented by $\mathrm{D}=\frac{T_{o}}{T}$ where $\mathrm{T}_{\mathrm{o}}$ is the turn $\mathrm{ON}$ time, for the switch $\mathrm{S}$. The duty ratio for non shoot through state is given by $1-\mathrm{D}-\mathrm{M}$, where $\mathrm{M}$ is modulation index, which is defined as $\mathrm{M}=$ (peak of reference voltage waveform / peak carrier (triangular) wave)

Another parameter to define the output and input voltage relationship is the boost factor, given by

$$
\mathrm{B}=\frac{1}{1-2 \frac{T_{o}}{T}}
$$

Also the modulation index is given by

$$
\frac{T_{o}}{T}=1-\mathrm{M}
$$

Therefore (13) will become

$$
\mathrm{B}=\frac{1}{2 M-1}
$$

The control parameters as defined in (13),(14) and (15), is promontory to the control of z-source inverter. Hence, forth result in the pulse width modulation of the ZSI, which result in modeled switching function as in (10),(11) and (12).

The PWM [7] control technique used in ZSI control is Sinusoidal PWM. As, in SPWM lower or upper three switches are turned on, whenever the applied triangular(carrier) waveform becomes greater than the maximum value or lower than the minimum value of the three reference waves.

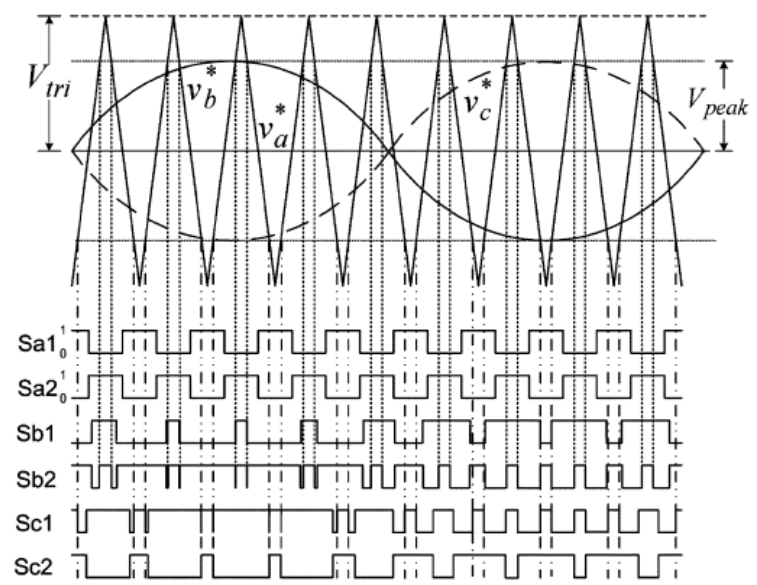

Fig.5 Six pulse inverter control scheme

In SPWM technique zero states forming during modulation is utilized for shoot through. During shoot through in zero state the shoot through ratio is kept constant, and the input voltage is applied across switches of the inverter bridge circuit.

The[8,9] strategy of one step conversion in ZSI, with low ripple and THD, is carried out by operating six switch circuit in four switch bridge operation and remaining two switches are used as a neutral point for two phase circuit. Consider for three phase "a", "b" and "c" connected to three legs of the bridge circuit, two switches corresponding to same leg is open together, which is not allowed in conventional inverter. For phase "a" leg switches to be open at once, phases "b" and "c" performs the shoot through process for the positive and negative cycles of reference wave, where phase "a" switches is operated without shoot through with $50 \%$ duty cycle. 


\section{Simulation And Results}

The discussed control techniques in this paper is applied to PV-grid interactive system. The PV array 5 cells connected in series to produce a PV voltage of $160 \mathrm{~V}$ is considered as a dc source to the ZSI. The Zimpedance network is framed with following parameters: $\mathrm{L}=2.7 \mathrm{mH}$ and $\mathrm{C}=340 \mu \mathrm{F}$. The load is considered to $250 \mathrm{~V}, 50 \mathrm{~Hz}$ grid line supplying a linear load of $\mathrm{L}_{\text {load }}=1.1 \mathrm{mH}, \mathrm{C}_{\text {load }}=2 \mu \mathrm{F}$ and $\mathrm{R}_{\text {load }}=3 \mathrm{ohm}$. The shoot through state of ZSI is represented as sudden rise in the three phase load current as shown in Fig.6. Ripples in the grid power is produced due to the change in the inductor current, during transients of non shoot through and shoot through.[10-12] These transients are also reflected as the dip in the capacitor voltage, before the shoot through state. Ripples in the power curve is reduced with the increasing modulation index M as shown in Fig. 7 and 10.

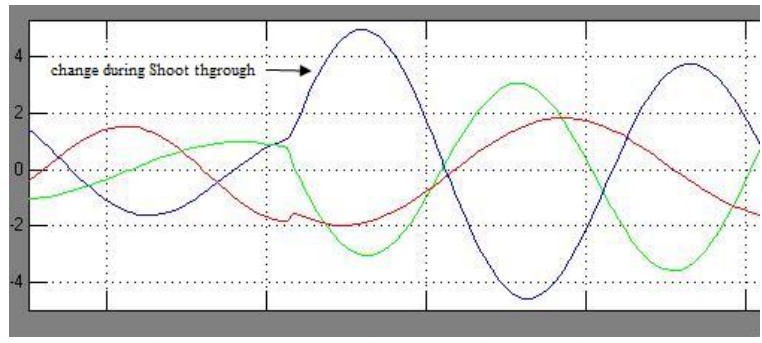

Fig.6 Load Current change during transients

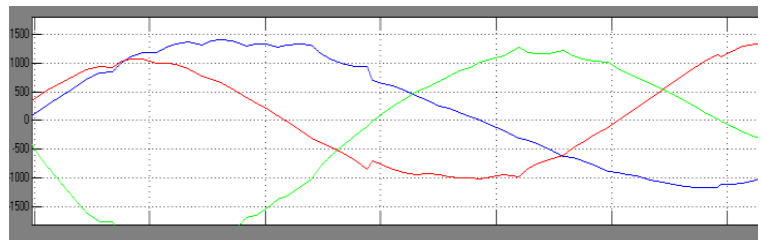

Fig. 7 Grid Power ripples at $\mathrm{M}=0.755$ due to inductor current

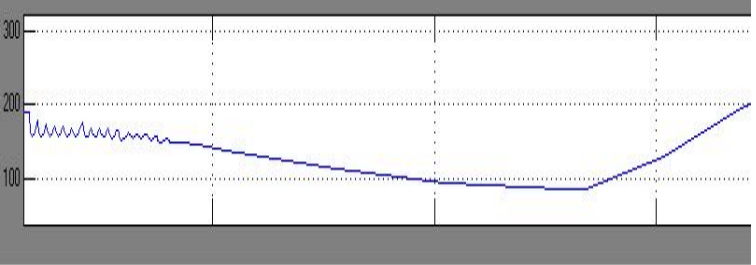

Fig. 8 Dip in the capacitor voltage before gaining rated value

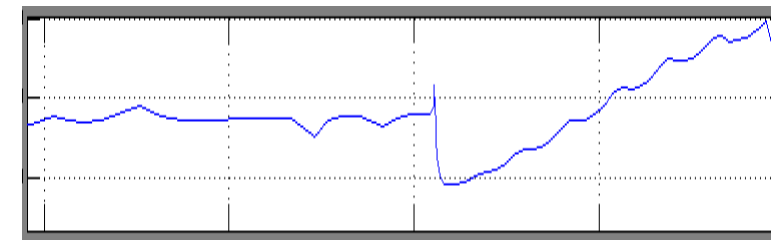

Fig. 9 Transients in the inductor current resulting from shoot through

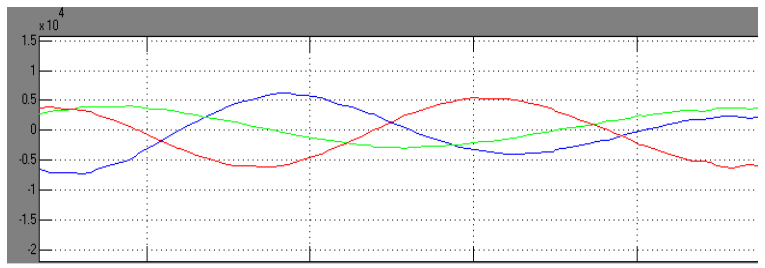

Fig. 10 Grid Power at $M=1$ (reduction in the ripples with increasing modulation index)

The magnitude of the output power is also improved with increasing modulation index.

\section{Conclusion}

The approach presented in the paper, is reflected in the model of the $\mathrm{Z}$ source inverter. The mathematical model is simulated in the MATLAB/SIMULINK software to study the characteristics of different parameters considered in the model. As the switching function plays a significant role in controlling the inverter output and hence, the grid current and power. Thus, modulation index of the inverter is controlled to suppress 
the ripples in the grid power waveform. The output power, as obtained is also changes due to change in the switching function of the inverter switches.

\section{References}

[1] Marcelo Gradella Villalva, Jonas Rafael Gazoli, and Ernesto Ruppert Filho "Comprehensive Approach to Modeling and Simulation of Photovoltaic Arrays” IEEE Transactions on Power Electronics, vol. 24, no.5, may2009

[2] Yi Huang, Miaosen Shen, Yi Huang, Miaosen Shen, and Jin Wang "Z-Source Inverter for Residential Photovoltaic Systems" IEEE Transactions on Power Electronics, vol. 21, no. 6, november 2006.

[3] Poh Chiang Loh, D. Mahinda Vilathgamuwa, Chandana Jayampathi Gajanayake, Yih Rong Lim, and Chern Wern Teo "Transient Modeling and Analysis of Pulse-Width Modulated Z-Source Inverter” IEEE Transactions on Power Electronics, vol. 22, no. 2, march 2007.

[4] Xiaogao Chen, Qing Fu, Shijie Yu, Longhua Zhou "Unified Control of Photovoltaic Grid-Connection and Power Quality managements" 2008 Workshop on Power Electronics.

[5] Miaosen Shen, Qingsong Tang, Fang Z. Peng "Modeling and Controller Design of the Z-Source Inverter with Inductive Load" 2007 IEEE

[6] Baoming Ge, Qin Le, Fang Zheng Peng, Dongsen Song, Yushan Liu and Abu Rub Haitham "An Effective PV Power Generation Control System using Quasi-Z Source Inverter with Battery" 2011 IEEE.

[7] Fabricio Bradaschia, Marcelo C. Cavalcanti, Pedro E. P. Ferraz, Francisco A. S. Neves, Euzeli C. dos Santos, Jr., Joao H. G. M. a Silva "Modulation for Three-Phase Transformerless Z- Source Inverter to Reduce Leakage Currents in Photovoltaic Systems" IEEE Transactions on Industrial Electronics, vol. 58, no. 12, december 2011

[8] Jingbo Liu, Jiangang Hu, and Longya Xu "Dynamic Modeling and Analysis of Z Source Converter-Derivation of AC Small Signal Model and Design-Oriented Analysis" IEEE Transactions on Power Electronics, vol. 22, NO. 5, september 2007

[9] Po XU, Xing ZHANG, Chong-wei ZHANG, Ren-xian,CAO and Liuchen CHANG "Study of Z-Source Inverter for Grid- Connected PV Systems" IEEE Conference Publications Year 2006.

[10] C. J. Gajanayake, D. Mahinda Vilathgamuwa, Poh Chiang Loh "Modeling and design of multi-loop closed loop controller for Zsource inverter for Distributed Generation" School of Electrical and Electronic Engineering 2006.

[11] Babak Farahangi, Shahrokh Farahangi, "Applicationof z-source Converter in photovoltaic grid connected transformer less inverter" Electrical Power quality and utilization vol. 12 no.2, 2006

[12] I.Venkatraman and T.Annamalai " $Z$ Source Inverter Interfacing with Photovoltaic Cells" International Journal of Communications and Engineering Volume 01- No.1, Issue: 04 March2012

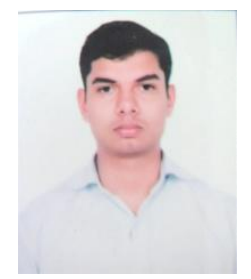

Varun Avasthy was born in Uttar Pradesh, India on August 26, 1988. He has received his B.Tech degree in Electrical \& Electronics Engineering in the year of 2010 from Uttar Pradesh Technical University, Lucknow. He is presently pursuing his M.Tech degree in Power Electronics and Drives from SRM University, Chennai. He is a IEEE member and his area of interest involves in Power Electronics, Grid Interactive Solar Photovoltaic Power system.

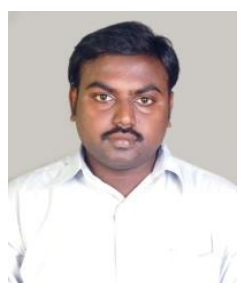

R.Sridhar was born in 1980 in Tamil Nadu, India. He received his B.E degree from Madurai Kamaraj University, Tamil Nadu in 2002 and the M.Tech degree in Power Electronics \& Drives from SASTRA University in 2004. Presently he is pursuing his PhD degree in SRM University, Chennai, India. Currently he is an Asst. Professor in EEE Department in SRM University. His current research interests include Solar Energy (performance enhancement), Wind Electric Conversion Systems, Analysis of converters, and Electrical Machines. 